\title{
Social Media Addiction and Mental Health Among University Students During the COVID-19 Pandemic in Indonesia
}

\author{
Sujarwoto $^{1}$ (D) $\cdot$ Rindi Ardika Melsalasa Saputri $^{2} \cdot$ Tri Yumarni $^{3}$
}

Accepted: 22 June 2021/ Published online: 1 July 2021

(C) The Author(s), under exclusive licence to Springer Science+Business Media, LLC, part of Springer Nature 2021

\begin{abstract}
Deteriorating mental health among university students during the COVID-19 pandemic is a serious worldwide public health concern. This study aims to examine the linkage between social media addiction and mental health of university students in Indonesia and to address whether family relationship and religiosity may mitigate the harmful effects of social media on the mental health of students at this time. We collected data from 709 students at universities across the country between June 3 and June 20, 2020. Mental health was measured using 10 items validated by the Center for Epidemiological Studies-Depression (CES-D) scale. We found that students with higher social media addiction scores had a greater likelihood of experiencing mild depression (OR 1.07, CI: 1.02-1.12). Students who had good relationships with their parents and were more religious showed better mental health than those who had poor relationships with their parents and were less religious. This study suggests the need to mitigate university students' mental health risks through reducing social media addiction while encouraging family relationships and religiosity during the pandemic.
\end{abstract}

Keywords Mental health · Social media addiction · University students · COVID-19 pandemic · Indonesia

Studies have convincingly documented that social media addiction is common among university and college students and that this addiction is harmful to their mental health (Berryman et al., 2018; Cain, 2018; Kircaburun et al., 2018). Given the increasingly prominent role of

Sujarwoto

sujarwoto@ub.id

Rindi Ardika Melsalasa Saputri

rindiams@student.ub.ac.id

Tri Yumarni

triyum26@gmail.com

Extended author information available on the last page of the article 
social media in university students' lives during the COVID-19 pandemic, understanding the effect of social media on their mental health is critical. The dominance of online learning during lockdown is forcing many university students to live via the internet and social media. With limited physical and social activities outside the home and more time spent with mobile phones and the Internet, social media addiction among students may worsen during the coronavirus pandemic. Hence, the risks to their mental health come not only from the pandemic situation itself, but also from their increased Internet and social media use. Recent evidence suggests that too much time spent on social media has been taking a toll on the mental health of users during the COVID-19 pandemic in Wuhan (Gao et al., 2020).

Studies suggest that strong family relationships and personal religiosity may mitigate students' mental health challenges during the pandemic. Studies have documented that good family relationships reduce the likelihood of depression among students (Chen et al., 2020; ul Haq et al., 2018; Wu et al., 2020; Zhai et al., 2016). During this pandemic, maintaining good family relationships is necessary for students' mental health, since many must spend more time at home with their families in order to comply with social isolation and distancing measures (Chen et al., 2020; Wu et al., 2020). Being thus confined during this uncertain and stressful time may strain family relationships if students are unable to build good relationships with those in their households. On the other hand, students who are able to cultivate good connections with their parents, siblings, and other family members may be better able to cope with the stressful situation and therefore to maintain their mental health in social isolation $(\mathrm{Wu}$ et al., 2020).

Previous studies have also generally found religiosity to benefit students' mental health (Hackney \& Sanders, 2003; Pajević et al., 2005). Religiosity improves students' mental health by promoting psychic development, healthy states of mind, and emotional stability (Pajević et al., 2005). On the other hand, it also reduces the tendency to high-risk behaviour, impulsive reactions, and aggression (Kirchner \& Patino, 2010). Other scholars suggest that religiosity benefits mental health via the mechanism of religious social support, defined as the emotional and tangible support that an individual receives, provides, and expects from their religious community. Krause et al. (2001) explain that religious social support can be quantified by the size of an individual's social network as a result of participation in religious and spiritual activities (Debnam et al., 2012). Hence, religiosity may sustain the mental health of students during the outbreak by offering both social support and spiritual fulfilment.

Accordingly, this study aims to examine the association between social media addiction and mental health among university students in Indonesia, as well as examine whether family relationships and religiosity may mitigate the harmful effects of social media on the mental health of these students during the COVID-19 pandemic. Existing studies suggest that social media addiction harms students' mental health (Cain, 2018; Macaskill, 2013; ul Haq et al., 2018; Zhai et al., 2016), and that family relationships and religiosity benefit students' mental health (Hackney \& Sanders, 2003; Pajević et al., 2005). Family relationships and religiosity may therefore reduce the harmful effects of social media addiction on students' mental health during the pandemic through social and spiritual means (Debnam et al., 2012). Hence, this study proposes two hypotheses. $\mathrm{H}_{1}=$ social media addiction is associated with lower students' mental health. $\mathrm{H}_{2}=$ students who have higher social media addiction but have a good relationship with their families or perceive themselves as religious individuals are likely to have better mental health than students who have higher social media addiction but have a poor relationship with their families or perceive themselves as non-religious individuals. Our goal in this paper is to test whether these hypotheses can be confirmed for Indonesian 
university students in the early stages of the pandemic. To our knowledge, this is the first study to examine university students' mental health in Indonesia in the context of the COVID-19 outbreak. Thus, the findings of this study may provide new information for researchers and policy makers seeking to understand the mental health of students during the pandemic.

\section{Materials and Methods}

\section{Contexts}

This study was conducted in the setting of Indonesian universities, where, like schools around the world, face-to-face classroom teaching has been replaced by online learning since March 18, 2020. Students are not allowed to be at their universities. For their safety, many universities have encouraged students to return to their families, a move that may be seen unfavourably by some students as a loss of their everyday freedom. Meanwhile, physical distancing and lockdown policies force citizens to limit social activities outside home. Unlike in normal times, most are currently unable to engage in collective physical exercise, go with friends to malls or supermarkets, meet in coffee shops, or even go to the cinema, given that most of those facilities have been closed.

Most try to meet their social needs via social media, which both connects them with friends and provides entertainment during the tedious hours at home. A 2019 survey by the Indonesian National Bureau of Statistics reported that 72 million young Indonesians used the Internet regularly and that more than a half of those used social media such as Facebook, WhatsApp, Instagram, and YouTube (BPS, 2020). Recent statistics also show that during the pandemic, social media platforms such as WhatsApp, Line, Telegram, and Facebook have experienced a $40 \%$ increase in total users in Indonesia, while users of online game apps have increased by 24\% (Kata Data Indonesia, 2020). On average, WhatsApp and Facebook users open their account 100-200 times a day and 10-15 times a day, respectively. The average amount of time Indonesians spend accessing the Internet and social media during the outbreak has also increased markedly, from about 5.5 to almost $8 \mathrm{~h}$ a day. Most Internet and social media users are young adults (16-24 years old) (Kata Data Indonesia, 2020). With the increasing time and intensity of Internet use by young adults, especially university students, during the pandemic, the risk of addiction to social media and the Internet among this group is higher than in typical situations. These risks may result in harm to their mental health.

Strong family relationships and religiosity are two social and cultural characteristics of Indonesian university students, which are also reflected in Indonesian society at large (French et al., 2020; Purwono et al., 2019). Indonesians are very family-oriented, meaning that family relationships are very close, and characterised by mutual love and an obligation to take care of each other. We believe that this important social feature can benefit the mental health of university students who must adapt to a stressful situation during the pandemic. Good family relationships help students to feel safe and to enjoy their time with family members during quarantine; most importantly, good relationships reduce the risk of experiencing depression during the pandemic.

Indonesia's social and cultural life is also characterised by strong religiosity. The 2012 Gallup Survey reported that Indonesia was one of the five most religious countries in the world (Gallup, 2012). According to the survey, almost all Indonesians (99\%) said that religion played an important role in their daily lives. Religious activities are also part of Indonesia's university 
education: religion and religiosity are compulsory aspects of the national curriculum. Religious activities, such as praying at university mosques, churches, and Buddhist temples, or attending religious talks, are important cultural activities that are part of students' everyday lives. Likewise, most Indonesian families are very religious. Throughout the country, regular religious activities form part of families' and communities' everyday lives. Thus, we expect that religiosity may benefit the mental health of university students during the pandemic.

\section{Ethical Clearance}

This study received ethical approval from the Ministry of Education and Culture, University of Brawijaya (Number 330/EC/KEPK/2020).

\section{Online Survey}

We used an online survey platform as the most feasible method of data collection due to the nationwide university lockdown policy. Before data collection, pre-testing of the online survey platform was conducted, asking 10 eligible participants whether they could easily access the link to the online questionnaire, and whether they experienced any trouble opening and using the survey link. We also asked them to identify any vague or overly complicated questions or response options. All participants reported that they easily accessed and used the link and that all the questions and responses in the questionnaire were clear and easy to understand. The average time to complete the survey was $10-15 \mathrm{~min}$. Validity and reliability tests were applied to the questionnaire. The validity coefficient (correlation coefficients) for CES-D items and BSMAS items was 0.791 and 0.751 respectively, while the coefficient alpha (Cronbach's alpha) for CES-D was 0.901 and for BSMAS was 0.819. All measures of validity and reliability tests indicate both instruments are statistically acceptable (Tavakol \& Dennick, 2011). In addition, to estimate the reliability of the entire survey, the SpearmanBrown correction was applied. Kappa values $\geq 0.70$ indicate the instrument was statistically reliable.

The online survey was available from June 3 to June 20, 2020, about 3 months after university students in Indonesia were required to begin studying from home due to the pandemic. The survey was created using a template from Google Forms for business to enhance its functionality and security. The survey link was distributed to university stakeholders representing seven Indonesian regions (Sumatra, Jawa and Bali, Kalimantan, Sulawesi, Nusa Tenggara, Maluku, and Papua), who distributed the online questionnaire to their students. These university stakeholders asked lecturers to share the survey link to their students via email or student WhatsApp groups. We asked the lecturers to explain to students the purpose of the survey. Written informed consent was obtained from all respondents.

We used stratified random sampling technique to determine respondents in this study. First, we stratified respondents into 6 major university regions in Indonesia: Sumatra, Jawa and Bali, Kalimantan, Sulawesi, Nusa Tenggara, Maluku, and Papua. Second, we allocated $~ 116$ respondents per region to be randomly selected for the study. With a confidence level 1.96, margin of error 0.05 , design effect 1.5 , and expected response rate 0.8 , we found estimate sample 125 respondents per region (Verma \& Verma, 2020). In total, we collected data from 709 participants, representing students in each of the above-mentioned regions. The dataset for this study can be accessed in open platform database OSF in the following links: https://osf.io/ $\mathrm{d} 2 \mathrm{mj} /$. 


\section{Measures}

Mental health was measured using the CES-D scale, which consists of 10 items asking respondents to rate how often in the past week they have experienced symptoms associated with depression (Eaton et al., 2004). These include whether the student was bothered by things that usually do not bother them; whether the student had trouble concentrating on what they were doing; whether the student felt depressed, fearful, or lonely; whether the student felt everything they did was an effort; whether the student felt hopeful about the future; whether the student had trouble sleeping; and whether the student felt happy. For Indonesia's context, the 10 items of the CES-D scale were validated and used in a large national survey, the longitudinal Indonesia Family Life Survey 1993-2014 (Strauss et al., 2016). It also has been widely used by researchers and practitioners to study mental health in Indonesia (Fahmi et al., 2019; Tampubolon \& Hanandita, 2014; Tran et al., 2019). Responses were recorded using ordinal scale ranges from 0 to 3 ( $0=$ rarely or none of the time, or $0-1$ day in a week; $1=$ some or little of the time, or 1-2 days in a week; 2 = moderately or much of the time, or 3-4 days in a week; $3=$ most or almost all the time, or 5-7 days in a week). CES-D score was calculated as the sum of responses to the 10 items after the positively phrased items were reverse-coded. Scores range from 0 to 30, with high scores indicating higher levels of depressive symptoms (Sujarwoto et al., 2019). A cutoff point of 10 is used to identify depression in an individual (Fahmi et al., 2019; Tran et al., 2019). In this study, we use both continuous scores and binary scales of mental depression.

Social media addiction was measured using the Bergen Social Media Addiction Scale (BSMAS), which consists of six self-reporting items intended to measure an individual's risk of social media addiction on the Internet (Andreassen et al., 2017). The BSMAS applies the six core addiction elements (salience, mood modification, tolerance, withdrawal, conflict, and relapse) proposed by Griffiths (2014) to assess the experience of using social media (Andreassen et al., 2016). In this survey, responses were recorded using ordinal scale ranges from 1 to 5 ( $1=$ very rarely; $2=$ rarely; $3=$ sometimes; $4=$ often; $5=$ very often). BSMAS score was calculated as the total sum of responses to the 6 items asked to respondents. A higher score on the BSMAS indicates stronger addiction to social media, and a BSMAS score over 19 indicates that an individual is at risk of developing problematic social media use (Bányai et al., 2017). The 6 items of BSMAS scale were validated and used in previous studies in the Indonesian context (Herawati, 2019; Ratri, 2018). The detailed CES-D and BSMAS scales used in this study can be seen in the Supplementary file 1 .

We used a single measure of religiosity, following Gorsuch and McFarland (1972), who suggested that a single measure is sufficient to indicate an intrinsic pro-religious position. In this study, religiosity was measured by asking participants to rate themselves as either very religious, religious, somewhat religious, or not religious in response to the question, "How religious are you?" Family relationships were measured with two questions asking participants to rate their relationships with parents and siblings: "How is your relationship with your parents?" ( 1 = not good at all, $2=$ not good, 3 = neutral, 4 = good, 5 = very good) and "How is your relationship with your siblings?" $(1=$ not good at all, $2=$ not good, $3=$ neutral, $4=$ good, 5 = very good $)$ (Moon \& Rao, 2010). Data collected on the socio-economic characteristics of students and parents included age and sex of students, parental income, parental job status, and parental marital status. 


\section{Statistical Analysis}

Statistical analyses were conducted as follows. First, to test the association between social media addiction and mental health, we used Poisson's regression. The same technique was used to accommodate the skewed and non-negative distribution of CES-D scores (Harris et al., 2012; Hilbe, 2014). Second, we used logistic regression to estimate the probability of a student's depression. Marginal effects were also presented to examine how CES-D score and depression change when BSMAS, relationship with parents, and religiosity change. Third, to test whether religiosity and relationship with parents mitigate the association between social media and mental health, we created interaction variables of both mediators and BSMAS scores. We used Poisson's regression to estimate the interaction variables on CES-D score. The maximum likelihood (ML) estimator was used to estimate all models; for the probability model, we also reported the odds ratio (OR) (Drukker, 2010). STATA 16 was used to estimate the models.

\section{Results}

\section{Descriptive Characteristics of Participant Samples}

Table 1 presents the descriptive characteristics of the participants. The average age of participants was 24 years old; most were female $(62 \%)$ and lived with their parents $(74 \%)$. Seventy-two percent of participants had mild depression issues. The average CES-D score was 13.37 (SD 5.15, range 0-28), which was slightly higher than the result for the average nonsenior adult in the 2014 Indonesia Family Life Survey. The average social media addiction score was quite high, at 16.79 (SD 4.03, range 6-24). Compared to previous studies of social media addiction in Indonesia (Ratri, 2018), this average score was slightly higher. Most of the participants reported having good relationships with their parents and siblings, and being religious. Most respondents' parents were working in the formal sector and had incomes between 2 million and 5 million rupiah per month (USD 143-357). Eleven percent of participants' parents were divorced, and 3\% of participants had parents who were both deceased.

\section{Poisson Regression Results}

Table 2 presents the results of the Poisson regression. Model A describes correlations between BSMAS and CES-D scores. Higher social media addiction scores are associated with poorer mental health (Coef. $=0.02, \mathrm{CI}=0.02-0.03$ ). Model B includes students' reports of their relationship to their parents and their perceived religiosity. Controlling for students' and parents' socio-economic characteristics, higher social media addiction scores are associated with poorer mental health (Coef. $=0.01, \mathrm{CI}=0.01-0.02$ ). Students who reported having good relationships with their parents (Coef. -0.10 , CI: -0.13 to -0.07 ) and being religious (Coef. -0.08 , CI: -0.12 to -0.04 ) were likely to have a lower risk of mental health issues. Female and older students had higher CES-D scores than male and younger students. The job status, income, and marital status of students' parents were not significantly associated with their mental health. There was no difference in mental health status between those students who reported living in the same household as their parents and those who did not. 
Table 1 Descriptive characteristics of sample

\begin{tabular}{|c|c|c|c|c|}
\hline Variables & $\%$ or mean & SD & Min & $\operatorname{Max}$ \\
\hline \multicolumn{5}{|l|}{ University students' characteristics } \\
\hline CES-D score & 13.37 & 5.16 & 0 & 28 \\
\hline IFLS CES-D score for respondent age 17-59 (reference) & 13.35 & 5.13 & 0 & 28 \\
\hline Mildly depressed & $72 \%$ & & 0 & 1 \\
\hline Not depressed & $28 \%$ & & 0 & 1 \\
\hline Age & 23.64 & 7.24 & 17 & 59 \\
\hline Female & $62 \%$ & & 0 & 1 \\
\hline Male & $38 \%$ & & 0 & 1 \\
\hline Live in parents' house & $74 \%$ & & 0 & 1 \\
\hline Live away from parents' house & $26 \%$ & & 0 & 1 \\
\hline BSMA (Bergen Social Media Addiction) & 16.79 & 4.03 & 6 & 24 \\
\hline BSMA in another large sample survey (reference) & 13.79 & 3.03 & 6 & 21 \\
\hline Have a good relationship with parents & 3.48 & 0.68 & 0 & 4 \\
\hline Have a good relationship with siblings & 4.00 & 1.26 & 0 & 5 \\
\hline Perceive self as religious & 3.02 & 0.51 & 1 & 4 \\
\hline \multicolumn{5}{|l|}{ Parent characteristics } \\
\hline Formal job & $66 \%$ & & 0 & 1 \\
\hline Informal job & $34 \%$ & & 0 & 1 \\
\hline$\geq 10$ million rupiah (1st quartile) & $10 \%$ & & 0 & 1 \\
\hline$\geq 5-10$ million rupiah (2nd quartile) & $19 \%$ & & 0 & 1 \\
\hline$\geq 2-5$ million rupiah ( $3 \mathrm{rd}$ quartile) & $38 \%$ & & 0 & 1 \\
\hline$\leq 2$ million rupiah (4th quartile) & $33 \%$ & & 0 & 1 \\
\hline Married & $85 \%$ & & 0 & 1 \\
\hline Divorced & $11 \%$ & & 0 & 1 \\
\hline Widowed & $1 \%$ & & 0 & 1 \\
\hline Both deceased & $3 \%$ & & 0 & 1 \\
\hline
\end{tabular}

\section{Logit Regression Results}

Further analysis was conducted to estimate the probability of student depression. Table 3 shows the logit regression results. Model A shows that students with higher social media addiction scores are 1.09 times more likely to be experiencing depression than those with lower scores (OR 1.09, CI: 1.05-1.14). Model B includes relationship to parents and perceived religiosity. Social media addiction again appears to harm mental health, whereas religiosity and good relationships with parents benefited student mental health (OR 0.58, CI: $0.42-0.80$ and OR 0.58 , CI: $0.39-0.84$ respectively). Model C demonstrated the same results, while also establishing that no other socio-economic characteristics were significantly associated with depression.

Figures 1,2, and 3 present marginal effects that examine how CES-D scores of depression change as BSMAS, religiosity, and relationship with parents change, while other factors are held constant. An increase in BSMAS of $1 \%$ corresponds to an average increase in CES-D score of 11 times for males and 12 times for females, and an average increase in depression of $54 \%$ for males and $61 \%$ for females. On the other hand, an increase of religiosity of $1 \%$ corresponds to average decrease in CES-D score of 16 times for males and 18 times for females, as well as an average decrease in depression of $73 \%$ for males and $78 \%$ for females. Finally, an increase in relationship quality with parents corresponds to an average decrease in CES-D score of 13 times for males and 15 times for females, and thereby an average decrease in depression of $78 \%$ for males and $83 \%$ times for females. 
Table 2 Poisson regression results

\begin{tabular}{|c|c|c|c|c|c|c|c|c|c|c|c|c|}
\hline & \multicolumn{4}{|c|}{ Model A } & \multicolumn{4}{|c|}{ Model B } & \multicolumn{4}{|c|}{ Model C } \\
\hline & \multirow[t]{2}{*}{ Coef. } & \multirow[t]{2}{*}{ S.E. } & \multicolumn{2}{|l|}{$95 \% \mathrm{CI}$} & \multirow[t]{2}{*}{ Coef. } & \multirow[t]{2}{*}{ S.E. } & \multicolumn{2}{|l|}{$95 \% \mathrm{CI}$} & \multirow[t]{2}{*}{ Coef. } & \multirow[t]{2}{*}{ S.E. } & \multicolumn{2}{|l|}{$95 \% \mathrm{CI}$} \\
\hline & & & Lower & Upper & & & Lower & Upper & & & Lower & Upper \\
\hline BSMAS & $0.02 *$ & 0.00 & 0.02 & 0.03 & $0.02 *$ & 0.00 & 0.01 & 0.02 & $0.01 *$ & 0.00 & 0.01 & 0.02 \\
\hline $\begin{array}{l}\text { Have a good } \\
\text { relationship } \\
\text { with parents }\end{array}$ & & & & & $-0.10^{*}$ & 0.02 & -0.13 & -0.07 & $-0.10^{*}$ & 0.02 & -0.13 & -0.07 \\
\hline $\begin{array}{l}\text { Have a good } \\
\text { relationship } \\
\text { with siblings }\end{array}$ & & & & & -0.02 & 0.01 & -0.03 & 0.00 & -0.01 & 0.01 & -0.03 & 0.00 \\
\hline $\begin{array}{l}\text { Perceive self as } \\
\text { religious }\end{array}$ & & & & & $-0.09^{*}$ & 0.02 & -0.13 & -0.05 & $-0.08 *$ & 0.02 & -0.12 & -0.04 \\
\hline Age & & & & & & & & & $0.00 *$ & 0.00 & -0.01 & 0.00 \\
\hline Female & & & & & & & & & $0.10^{*}$ & 0.02 & 0.06 & 0.15 \\
\hline Formal job & & & & & & & & & -0.01 & 0.02 & -0.06 & 0.04 \\
\hline $\begin{array}{c}\text { 1st income } \\
\text { quartile }\end{array}$ & & & & & & & & & 0.03 & 0.04 & -0.05 & 0.10 \\
\hline $\begin{array}{l}\text { 2nd income } \\
\text { quartile }\end{array}$ & & & & & & & & & 0.03 & 0.03 & -0.04 & 0.09 \\
\hline $\begin{array}{l}\text { 3rd income } \\
\text { quartile }\end{array}$ & & & & & & & & & 0.03 & 0.03 & -0.02 & 0.09 \\
\hline Divorced & & & & & & & & & -0.14 & 0.06 & -0.25 & -0.02 \\
\hline Widowed & & & & & & & & & 0.03 & 0.03 & -0.04 & 0.10 \\
\hline Live with parents & & & & & & & & & 0.07 & 0.03 & 0.01 & 0.12 \\
\hline Constant & $2.23 *$ & 0.05 & 2.14 & 2.31 & $2.96^{*}$ & 0.09 & 2.78 & 3.13 & $2.97 *$ & 0.10 & 2.77 & 3.18 \\
\hline
\end{tabular}

${ }^{*} p$ value $<5 \%$

\section{Moderation Analysis}

Moderation analysis was conducted to examine whether religiosity and relationship with parents may mitigate mental health problems experienced by students. Table 4 presents moderation analysis results for CES-D score. The interaction variables (having good relationship with parents $\times$ BSMAS and perceived religious person $\times$ BSMAS) are negative and have a significant correlation with CES-D score, indicating moderation effect of family relationship and religiosity on the relationship between social media addiction and mental health.

\section{Discussion and Conclusion}

Since social media has become more and more vital to the social life of university students during the pandemic, students may be at greater risk of social media addiction, which may be harmful to their mental health. In this study, we found that excessive social media use likely harms the mental health of university students in Indonesia, since students with higher social media addiction scores had a greater risk of experiencing mild depression. This finding corroborates Gao et al. (2020), who also suggested that excessive use of social media harmed mental health during the Wuhan outbreak.

Previous studies provide some explanation of how social media use can harm the mental health of university students in Indonesia during the COVID-19 outbreak. The first of these is 
Table 3 Odd ratio results

\begin{tabular}{|c|c|c|c|c|c|c|c|c|c|c|c|c|}
\hline & \multicolumn{4}{|c|}{ Model A } & \multicolumn{4}{|c|}{ Model B } & \multicolumn{4}{|c|}{ Model C } \\
\hline & \multirow[t]{2}{*}{ OR } & \multirow[t]{2}{*}{ S.E. } & \multicolumn{2}{|l|}{$95 \% \mathrm{CI}$} & \multirow[t]{2}{*}{ OR } & \multirow[t]{2}{*}{ S.E. } & \multicolumn{2}{|l|}{$95 \% \mathrm{CI}$} & \multirow[t]{2}{*}{ OR } & \multirow[t]{2}{*}{ S.E. } & \multicolumn{2}{|l|}{$95 \% \mathrm{CI}$} \\
\hline & & & Lower & Upper & & & Lower & Upper & & & Lower & Upper \\
\hline BSMAS & $1.09 *$ & 0.02 & 1.05 & 1.14 & $1.08 *$ & 0.02 & 1.03 & 1.12 & $1.07 *$ & 0.02 & 1.02 & 1.12 \\
\hline $\begin{array}{l}\text { Have a good } \\
\text { relation- } \\
\text { ship with } \\
\text { parents }\end{array}$ & & & & & $0.58^{*}$ & 0.10 & 0.42 & 0.80 & $0.57 *$ & 0.09 & 0.41 & 0.78 \\
\hline $\begin{array}{l}\text { Have a good } \\
\text { relation- } \\
\text { ship with } \\
\text { siblings }\end{array}$ & & & & & 0.86 & 0.07 & 0.73 & 1.02 & 0.87 & 0.08 & 0.73 & 1.03 \\
\hline $\begin{array}{l}\text { Perceive self } \\
\text { as } \\
\text { religious }\end{array}$ & & & & & $0.58^{*}$ & 0.11 & 0.39 & 0.84 & $0.60 *$ & 0.12 & 0.41 & 0.89 \\
\hline Age & & & & & & & & & 1.00 & 0.01 & 0.97 & 1.03 \\
\hline Female & & & & & & & & & 1.41 & 0.25 & 0.99 & 2.01 \\
\hline Formal job & & & & & & & & & 0.95 & 0.20 & 0.62 & 1.44 \\
\hline $\begin{array}{c}\text { 1st income } \\
\text { quartile }\end{array}$ & & & & & & & & & 1.32 & 0.46 & 0.67 & 2.62 \\
\hline $\begin{array}{c}\text { 2nd income } \\
\text { quartile }\end{array}$ & & & & & & & & & 1.07 & 0.30 & 0.62 & 1.85 \\
\hline $\begin{array}{c}\text { 3rd income } \\
\text { quartile }\end{array}$ & & & & & & & & & 1.23 & 0.28 & 0.78 & 1.94 \\
\hline Divorced & & & & & & & & & 0.57 & 0.26 & 0.23 & 1.40 \\
\hline Widowed & & & & & & & & & 1.34 & 0.41 & 0.74 & 2.43 \\
\hline $\begin{array}{r}\text { Live with } \\
\text { parents }\end{array}$ & & & & & & & & & 1.51 & 0.36 & 0.95 & 2.40 \\
\hline Constant & $0.57 *$ & 0.20 & 0.29 & 1.14 & $50.64 *$ & 44.10 & 9.19 & 279.10 & $30.82 *$ & 30.29 & 4.49 & 211.48 \\
\hline
\end{tabular}

the cacophonous input mechanism (Ellison et al., 2007). During the outbreak, online social media has been a key tool used by most university students to connect with their friends and families, to express opinions in their groups, and to obtain and share information. The uncertainty of the situation, uncertainty about their future, and the intensity of negative news related to COVID-19 may lead to frustration, harming students' mental health. The proliferation of fake news and hoaxes during the outbreak may also take a toll on the mental health of Indonesia's students. Another is the envy and bitterness mechanism (Jordan et al., 2011). Social envy is a common feature of online social media. Within their WhatsApp groups or on Facebook, students often compare themselves with others who may have higher social and/or economic status. This psychological behaviour may lead to depression as students feel deficient or defeated in the online social community. This psychosocial mechanism is indicated by the social rank theory of depression, which suggests that low self-perception of social rank is linked to depressive symptoms and suicide risk (Sturman, 2011).

Our study identified two factors that may benefit student mental health during the pandemic. Strong family relationships and religiosity are two social and cultural features of Indonesian university students that also reflect those of the wider Indonesian society (French et al., 2020; Purwono et al., 2019). We hypothesised that these two key characteristics might help to mitigate mental health issues among university students during the 


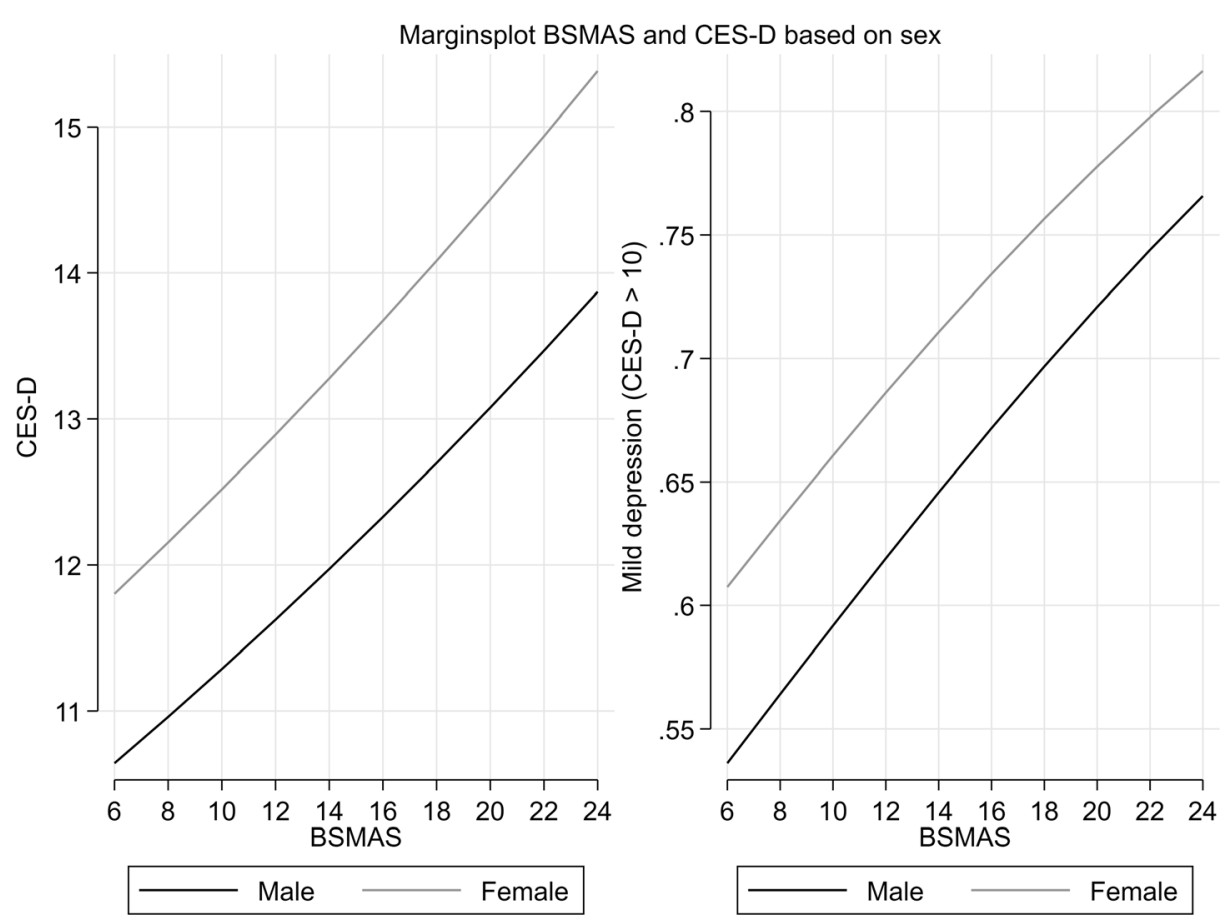

Fig. 1 Marginsplot BSMAS and CES-D based on sex

\section{Marginsplot religiosity and CES-D based on sex}
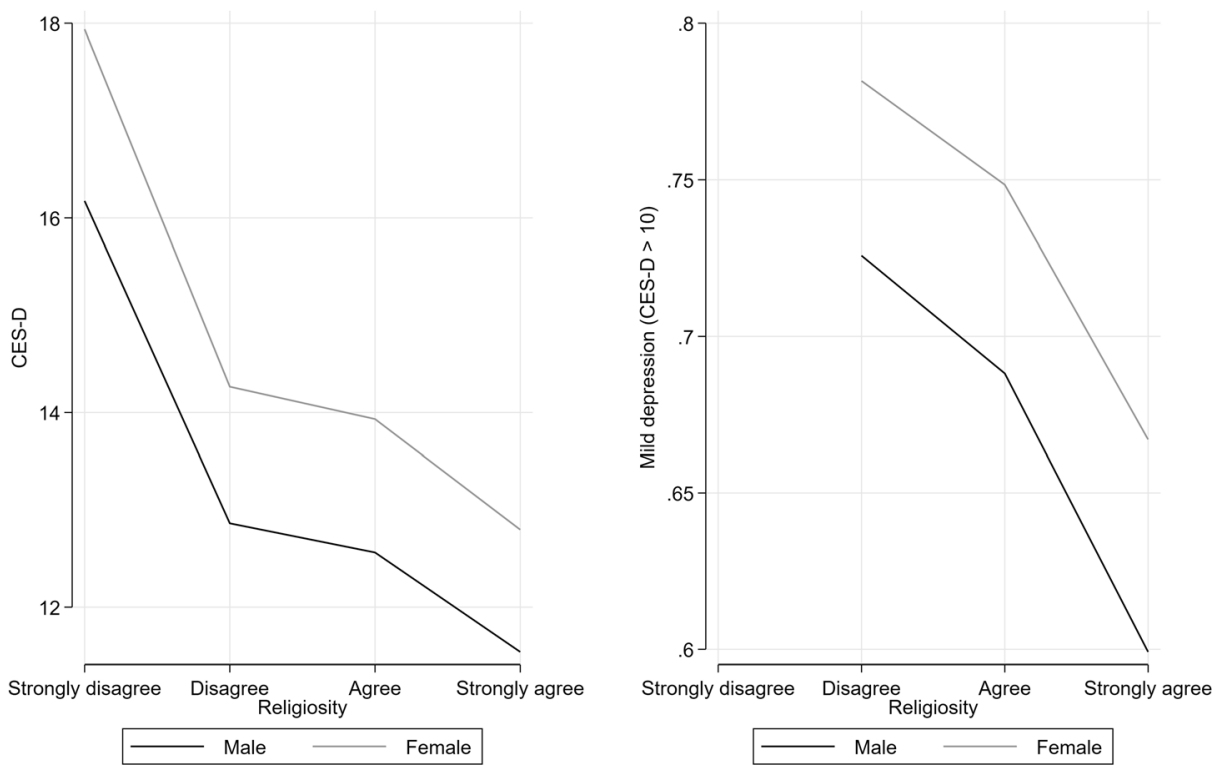

Fig. 2 Marginsplot religiosity and CES-D based on sex 
Marginsplot relationship with parents and CES-D based on sex
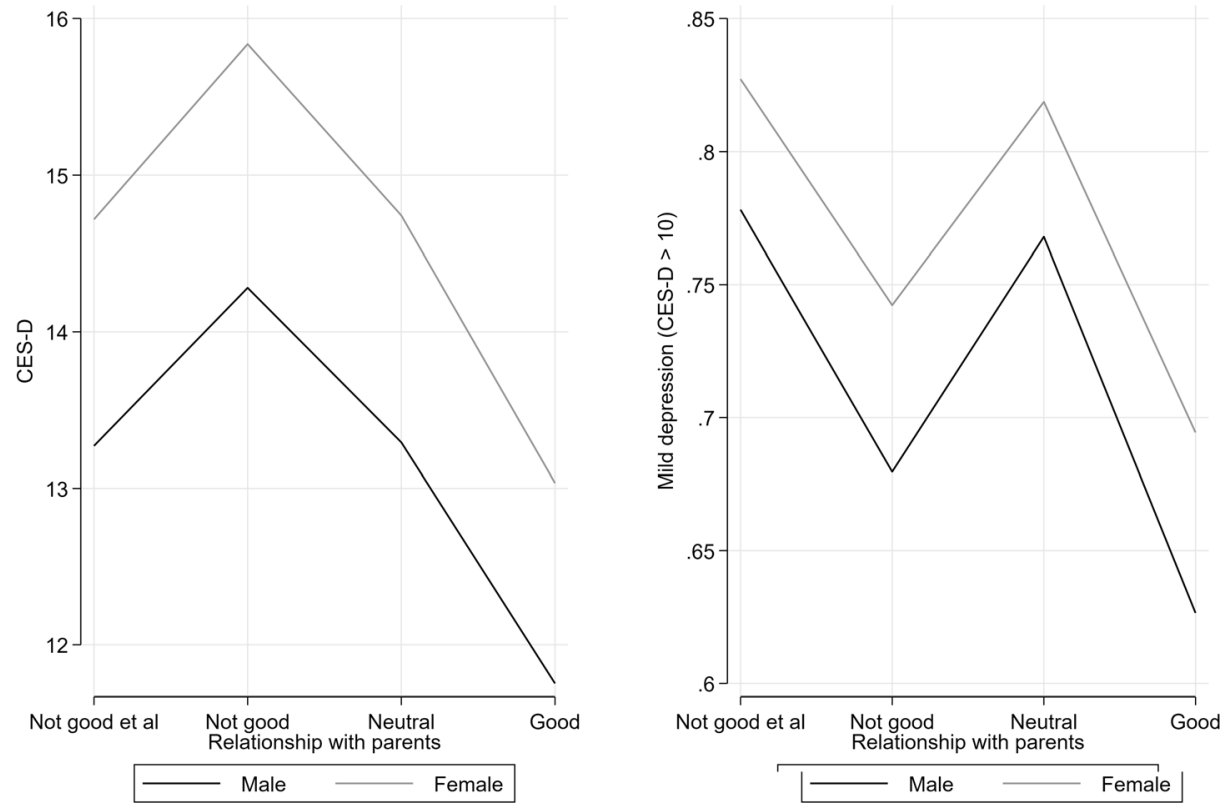

Fig. 3 Marginsplot relationship with parents and CES-D based on sex

pandemic. Confirming our hypothesis, we found that students who reported having good relationships with their parents and being religious had a lower risk of mental issues during

Table 4 Moderation analysis results

\begin{tabular}{|c|c|c|c|c|c|c|c|c|}
\hline & \multicolumn{4}{|c|}{ Model A } & \multicolumn{4}{|c|}{ Model B } \\
\hline & \multirow[t]{2}{*}{ Coef. } & \multirow[t]{2}{*}{ S.E. } & \multicolumn{2}{|l|}{$95 \% \mathrm{CI}$} & \multirow[t]{2}{*}{ Coef. } & \multirow[t]{2}{*}{ S.E. } & \multicolumn{2}{|l|}{$95 \% \mathrm{CI}$} \\
\hline & & & Lower & Upper & & & Lower & Upper \\
\hline BSMAS & 0.01 & 0.02 & -0.03 & 0.04 & 0.00 & 0.02 & -0.04 & 0.03 \\
\hline Have a good relationship with parents & -0.10 & 0.06 & -0.22 & 0.02 & -0.11 & 0.06 & -0.24 & 0.02 \\
\hline Perceive self as religious & $-0.18^{*}$ & 0.09 & -0.35 & -0.01 & $-0.18 *$ & 0.09 & -0.36 & -0.01 \\
\hline $\begin{array}{l}\text { Have a good relationship with parents } \times \\
\text { BSMAS }\end{array}$ & $-0.10^{*}$ & 0.02 & -0.13 & -0.07 & $-0.10^{*}$ & 0.02 & -0.13 & -0.07 \\
\hline Perceive self as religious $\times$ BSMAS & $-0.13 *$ & 0.06 & -0.24 & -0.01 & $-0.13 *$ & 0.06 & -0.24 & -0.01 \\
\hline Age & & & & & 0.00 & 0.00 & -0.01 & 0.00 \\
\hline Female & & & & & 0.11 & 0.02 & 0.06 & 0.15 \\
\hline Formal job & & & & & -0.01 & 0.02 & -0.06 & 0.03 \\
\hline 1st income quartile & & & & & 0.02 & 0.04 & -0.05 & 0.10 \\
\hline 2nd income quartile & & & & & 0.03 & 0.03 & -0.03 & 0.10 \\
\hline 3rd income quartile & & & & & 0.03 & 0.03 & -0.02 & 0.09 \\
\hline Divorced & & & & & -0.13 & 0.06 & -0.24 & -0.01 \\
\hline Widowed & & & & & 0.03 & 0.03 & -0.03 & 0.10 \\
\hline Live with parents & & & & & 0.07 & 0.03 & 0.01 & 0.12 \\
\hline Constant & $3.16^{*}$ & 0.32 & 2.54 & 3.78 & $3.25^{*}$ & 0.33 & 2.62 & 3.89 \\
\hline
\end{tabular}

$* p$ value $<5 \%$ 
the pandemic. These findings are consistent with those of other studies and suggest that a good family relationship helps reduce depression among students (ul Haq et al., 2018; Zhai et al., 2016). During this pandemic, maintaining good family relationships is necessary for students' mental health, since most are obliged to spend more time at home. Building good relationships with family members, especially parents, can help students to feel safe and to enjoy their time in isolation. Students who are able to maintain good connections with their parents may be better able to cope with the stressful situation and therefore to maintain their mental health during social isolation. Likewise, religious students experienced better mental health than non-religious students. The significant relationship of students' religiosity to their mental health confirms existing studies that have documented the benefits of religiosity for mental health in the contexts of both religious and secular countries. In these studies, religiosity may help sustain the mental health of students during the pandemic via the mechanisms of social support and spiritual fulfilment (Chen et al., 2020; Kirchner \& Patino, 2010; Wu et al., 2020).

Several limitations of this study should be acknowledged. First, this study was based on cross-sectional data. Therefore, the estimation results should be seen as associative rather than causative (Robins, 1999; Solem, 2015). Future studies would need to investigate causal effect using a longitudinal or cohort design, or another causal effect research design (Höfler, 2005). Second, this study includes only a limited number of the socio-economic characteristics of students and their parents. For example, we were unable to collect data on parental educational levels. Third, this study used an online survey suitable for rapid assessment, so some respondent bias may arise, which may also lead to bias in the estimation results (Wright, 2005). Fourth, this study used a simple indicator as a proxy to measure religiosity and family relationship. Future studies may use more complex and reliable instruments such as D.H. Olson's circumflex model for measuring family system functioning (Olson, 1993) as well as the centrality of religiosity scale (CRS) developed by Huber which is often used to measure religiosity in terms of religious beliefs and knowledge, religious feelings, and religious practices (Huber \& Huber, 2012). Fifth, the number of questions of CES-D scale and social media addiction scale is limited. Hence, the effectiveness and comprehensiveness of both measures are less likely guaranteed. Last but not least, this study used a non-random or selected sample. Thus, verification on the prevalence of depression as well as the mechanisms by which religiosity and family relationship on CES-D and depression is needed, using a properly selected sample as well as intervening variables.

Despite these limitations, the present study makes several noteworthy contributions to the literature on mental health as well as assisting university stakeholders and policy makers to understand the condition of students' mental health during the pandemic. First, our findings have established empirical evidence of university students' mental health status during the COVID-19 outbreak in Indonesia. Moreover, our findings have established evidence of the detrimental effects of excessive use of online social media on university students' mental health during this period (Gao et al., 2020). The study also suggests the benefits of good family relationships and religiosity during a time when students are largely isolated with their families. Finally, these findings imply that university stakeholders and policy makers need to pay more attention to the issues of student mental health problems and social media addiction as the pandemic continues. Unfortunately, most university stakeholders in Indonesia are not providing mental health support services for their students during this challenging time. 


\section{Declarations}

Ethics Approval This study received ethical approval from the Ministry of Education and Culture, University of Brawijaya, Number 330/EC/KEPK/2020. All participants were provided with an informed consent form before their participation.

Conflict of Interest The authors declare no competing interests.

\section{References}

Andreassen, C., Billieux, J., Griffiths, M., Kuss, D., Demetrovics, Z., Mazzoni, E., \& Pallesen, S. (2016). The relationship between addictive use of social media and video games and symptoms of psychiatric disorders: A large-scale cross-sectional study. Psychology of Addictive Behaviors, 30(2), 252-262.

Andreassen, C., Pallesen, S., \& Griffiths, M. (2017). The relationship between addictive use of social media, narcissism, and self-esteem: Findings from a large national survey. Addictive Behaviors, 64, 287-293.

Bányai, F., Zsila, Á., Király, O., Maraz, A., Elekes, Z., Griffiths, M., Andreassen, C., \& Demetrovics, Z. (2017). Problematic social media use: Results from a large-scale nationally representative adolescent sample. PLoS One, 12(1), 1-13.

Berryman, C., Ferguson, C. J., \& Negy, C. (2018). Social media use and mental health among young adults. Psychiatric Quarterly, 89(2), 307-314.

BPS. (2020). Survei Sosial Ekonomi Indonesia 2019. BPS.

Cain, J. (2018). It's time to confront student mental health issues associated with smartphones and social media. American Journal of Pharmaceutical Education, 82(7), 738-741.

Chen, B., Sun, J., \& Feng, Y. (2020). How have COVID-19 isolation policies affected young people's mental health?-Evidence from Chinese college students. Frontiers in Psychology, 11(1), 1-6.

Debnam, K., Holt, C. L., Clark, E. M., Roth, D. L., \& Southward, P. (2012). Relationship between religious social support and general social support with health behaviors in a national sample of African Americans. Journal of behavioral medicine, 35(2), 179-189.

Drukker, D. (2010). An introduction to GMM estimation using Stata. Paper presented at the German STATA Users' Group Meeting, unpublished.

Eaton, W., Smith, C., Ybarra, M., Muntaner, C., \& Tien, A. (2004). Center for Epidemiologic Studies Depression Scale: Review and revision (CESD and CESD-R).

Ellison, N., Steinfield, C., \& Lampe, C. (2007). The benefits of Facebook “friends:" Social capital and college students' use of online social network sites. Journal of Computer-Mediated Communication, 12(4), 11431168.

Fahmi, M., Panjaitan, N., Habibie, I., Siregar, A., Amarullah, G., \& Sunjaya, D. (2019). Does your neighborhood protect you from being depressed? A study on social trust and depression in Indonesia. BMC Public Health, 19(1), 1371-1379.

French, D., Purwono, U., \& Shen, M. (2020). Religiosity and positive religious coping as predictors of Indonesian Muslim adolescents' externalizing behavior and loneliness. Psychology of Religion and Spirituality, 1(1), 1-9.

Gallup, G. (2012). Global index of religiosity and atheism. In: WIN Gallup International. Recuperado el. Gallup International Press.

Gao, J., Zheng, P., Jia, Y., Chen, H., Mao, Y., Chen, S., et al. (2020). Mental health problems and social media exposure during COVID-19 outbreak. PLoS One, 15(4), 1-15.

Gorsuch, R., \& McFarland, S. (1972). Single vs. multiple-item scales for measuring religious values. Journal for the Scientific Study of Religion, 4(1), 53-64.

Griffiths, M. D., Kuss, D. J., \& Demetrovics, Z. (2014). Social networking addiction: An overview of preliminary findings. Behavioral addictions, 119-141.

Hackney, C., \& Sanders, G. (2003). Religiosity and mental health: A meta-analysis of recent studies. Journal for the Scientific Study of Religion, 42(1), 43-55.

Harris, T., Yang, Z., \& Hardin, J. (2012). Modeling underdispersed count data with generalized Poisson regression. The Stata Journal, 12(4), 736-747.

Herawati, E. (2019). Hubungan Tingkat Adiksi Media Sosial dan Tingkat Self-esteem dengan Interaksi Sosial pada Remaja SMA Batik 2 Surakarta Universitas Muhammadiyah Surakart. .

Hilbe, J. (2014). Modeling count data: Cambridge University Press. 
Höfler, M. (2005). Causal inference based on counterfactuals. BMC Medical Research Methodology, 5(1), 2836.

Huber, S., \& Huber, O. (2012). The centrality of religiosity scale (CRS). Religions, 3(3), 710-724.

Jordan, A., Monin, B., Dweck, C., Lovett, B., John, O., \& Gross, J. (2011). Misery has more company than people think: Underestimating the prevalence of others' negative emotions. Personality and Social Psychology Bulletin, 37(1), 120-135.

Kata Data Indonesia. (2020). Penggunaan WhatsApp dan Instagram Melonjak 40\% Selama Pandemi Corona. Retrieved from https://katadata.co.id/berita/2020/03/27/penggunaan-whatsapp-dan-instagram-melonjak-40selama-pandemi-corona. Accessed 27 March 2020.

Kircaburun, K., Alhabash, S., Tosuntaş, Ș., \& Griffiths, M. (2018). Uses and gratifications of problematic social media use among university students: A simultaneous examination of the Big Five of personality traits, social media platforms, and social media use motives. International Journal of Mental Health and Addiction, 37(1), 1-23.

Kirchner, T., \& Patino, C. (2010). Stress and depression in Latin American immigrants: The mediating role of religiosity. European Psychiatry, 25(8), 479-484.

Macaskill, A. (2013). The mental health of university students in the United Kingdom. British Journal of Guidance and Counselling, 41(4), 426-441.

Moon, S., \& Rao, U. (2010). Youth-family, youth-school relationship, and depression. Child and Adolescent Social Work Journal, 27(2), 115-131.

Olson, D. (1993). Circumplex model of marital and family systems: Assessing family functioning. Journal of Family Therapy, 22(1), 144-167.

Pajević, I., Sinanović, O., \& Hasanović, M. (2005). Religiosity and mental health. Psychiatria Danubina, 17(12), 84-89.

Purwono, U., French, D. C., Eisenberg, N., \& Christ, S. (2019). Religiosity and effortful control as predictors of antisocial behavior in Muslim Indonesian adolescents: Moderation and mediation models. Psychology of Religion and Spirituality, 11(1), 55-60.

Ratri, H. (2018). Hubungan Penggunaan Media Sosial Dengan Tingkat Harga Diri Remaja Di Sma Negeri 2 Jember (Publication Number 12) Universitas Jember].

Robins, J. (1999). Association, causation, and marginal structural models. Synthese, 121(2), 151-179.

Solem, R. (2015). Limitation of a cross-sectional study. American Journal of Orthodontics and Dentofacial Orthopedics, 148(2), 205-2010.

Strauss, J., Witoelar, F., \& Sikoki, B. (2016). The fifth wave of the Indonesia family life survey: Overview and field report (1st ed.). RAND Santa Monica.

Sturman, E. (2011). Involuntary subordination and its relation to personality, mood, and submissive behavior. Psychological Assessment, 23(1), 262-276.

Sujarwoto, S., Tampubolon, G., \& Pierewan, A. C. (2019). A tool to help or harm? Online social media use and adult mental health in Indonesia. International journal of mental health and addiction, 17(4), 1076-1093.

Tampubolon, G., \& Hanandita, W. (2014). Poverty and mental health in Indonesia. Social Science \& Medicine, $106(2), 200-227$.

Tavakol, M., \& Dennick, R. (2011). Making sense of Cronbach's alpha. International Journal of Medical Education, 2(22), 53-55.

Tran, T., Kaligis, F., Wiguna, T., Willenberg, L., Nguyen, H., Luchters, S., ... Fisher, J. (2019). Screening for depressive and anxiety disorders among adolescents in Indonesia: Formal validation of the centre for epidemiologic studies depression scale - revised and the Kessler psychological distress scale. Journal of affective disorders, 246 (2), 189-194.

ul Haq, M., Dar, I., Aslam, M., \& Mahmood, Q. (2018). Psychometric study of depression, anxiety and stress among university students. Journal of Public Health, 26(2), 211-217.

Verma, J., \& Verma, P. (2020). Determining sample size and power in research studies. Springer.

Wright, K. (2005). Researching Internet-based populations: Advantages and disadvantages of online survey research, online questionnaire authoring software packages, and web survey services. Journal of ComputerMediated Communication, 10(3), 10-34.

Wu, M., Xu, W., Yao, Y., Zhang, L., Guo, L., Fan, J., \& Chen, J. (2020). Mental health status of students' parents during COVID-19 pandemic and its influence factors. General Psychiatry, 33(4), 65-78.

Zhai, H., Chen, L., Yang, Y., Sun, H., Pan, H., He, J., et al. (2016). Family and college environmental exposures mediate the relationship between parental education and depression among college students. PLoS One, 11(3), 1-9.

Publisher's Note Springer Nature remains neutral with regard to jurisdictional claims in published maps and institutional affiliations. 


\section{Affiliations}

Sujarwoto $^{1} \cdot$ Rindi Ardika Melsalasa Saputri ${ }^{2} \cdot$ Tri Yumarni $^{3}$

1 Portsmouth Brawijaya Center for Global Health, Population and Policy \& Department of Public Administration, Universitas Brawijaya, Malang, Indonesia

2 Magister of Higher Education, Department of Public Administration, Universitas Brawijaya, Malang, Indonesia

3 Department of Public Administration, Universitas Brawijaya, Malang, Indonesia 